\title{
Aqidah Deviations in the Millennial Era
}

\author{
Sori Monang ${ }^{1}$, Bambang Saputra ${ }^{2}$, Anwar Fauzi ${ }^{3}$ \\ ${ }^{1}$ Lecturer in Universitas Islam Negeri Sumatera Utara, Indonesia \\ ${ }^{2}$ Universitas Padjajaran, Indonesia \\ ${ }^{3}$ Student in Universitas Islam Negeri Sumatera Utara, Indonesia \\ sorimonangq@gmail.com,bambang19002@mail.unpad.ac.id,fanwar004@gmail.com
}

\begin{abstract}
In religious life that occurs in this millennial era, there are many misunderstandings regarding the issue of aqidah and other faith issues. Thoughts, ideologies, and activities that are contrary to aqidah and sharia, of course, cannot just develop in the community because they will cause people's unrest and cause people to become victims of misguidance. Without the right aqidah one will fall prey to suspicion or accusations and also doubts so that gradually it will hinder people from the right view. People's behavior like this will inevitably lead to deviations in the implementation of religious teachings. Therefore, serious efforts must be made to stop and awaken them to return to the right path.
\end{abstract}

\section{Keywords}

Aqidah; deviation; millennial

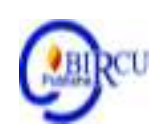

\section{Introduction}

Since ancient times until now Muslims are required to have a pure aqidah. If Muslims are very careful in practicing aqidah, then they can be protected from the dangers of shirk, to maintain or achieve goals so that they avoid problems that can encourage people to fall into deviations from the creed. Aqidah as a value system that is very competent in all aspects of Islamic society life. Where this belief can function as a light to achieve the goal of life, namely the salvation of the world and the hereafter.

In living life in this millennial era, there are many challenges, especially in religious life. On the one hand, da'wah activities run smoothly and various basic Islamic values are freely voiced without significant obstacles. But on the other hand, with this freedom, sects or groups that voice thoughts, ideas and activities that are contrary to Islamic creed and sharia can freely move and develop in society.

Deviations that are contrary to the Islamic creed, of course, should not develop in the community because they can cause unrest and are also feared to mislead many people. Therefore, there must be a serious effort to stop the flow so that people can return to the right path.

Ulama as heirs of the prophet also have a big role and responsibility in guiding the people to remain istiqamah in carrying out true Islamic values as taught by the Prophet $\square$. Therefore, scholars must be firm, wise and wise in dealing with any deviations, both related to Islamic creed and sharia. Indecisiveness of attitude will make deviations in aqidah and sharia increasingly widespread and widespread. 


\section{Research Method}

The research method used in this study used library research methods and qualitative methods to obtain descriptive data. The data collection used in this research is through library research, and the source of research data comes from sources collected by the library. Literature research in question is research whose data sources include written materials published in the form of books, scientific journals, newspapers, and magazines.

\section{Results and Discussion}

\subsection{Aqidah and its position}

The position of aqidah has a very important role in the life of a Muslim. Aqidah is the axis or core where is the purpose of human life.

Aqidah in general is belief, faith, belief deeply and correctly and then realize it in actions. Whereas in Islam, it means fully believing in the oneness of Allah, where Allah is the holder of the highest authority and regulator of all that is in the universe.

Aqidah is likened to the foundation of a building. So aqidah must be designed and built first than other parts. Aqidah must also be built strong and sturdy so that it is not easily shaken which can cause the building to collapse. The building referred to here is the true, comprehensive, and perfect Islam.

Without having a solid and established aqidah and faith, one will easily become a victim of the enormity of social media and IT advancements in this millennial era, including in breaking down the level of science and sheer doubt. If this continues, it will hinder a valid understanding of the straight path, it will be very worrying to undermine the happiness of life in this world and the hereafter. As one of the impacts, recently there are often human attitudes and behaviors that deviate from the aqidah. This deviation is a real misguidance and destruction as well as threatening the future regeneration of Islam.

The essence of the Islamic faith is monotheism. Because that's Islam brought by the Prophet Muhammad $\square$ among others, to straighten the aqidah of human beings who experience deviations. Tawhid is the main task in the life of humans and jinn. Tawhid is also the first imposed by Allah on all His servants. The command to monotheism precedes all other commands of Allah. As stated in the word of Allah SWT which means:

"So know that there is no God worthy of worship besides Allah, and ask Allah to forgive you for your sins, the sins of the believing men and the sins of the believing women" (Surah Muhammad 47:19).

In this verse, Allah commands to first learn and understand the meaning of laa ilaaha illallahu which literally means that there is no god worthy of worship except Allah. By recognizing and practicing it, a servant will be able to unite. 


\subsection{The Main Factors of Deviation of Aqidah}

In the KBBI dictionary the word "deviation" comes from the word intersection, which means something that separates (turns, branches) from a straight line. Deviance refers to processes, methods and deviant behavior or behavior outside the applicable rules. Deviation from the true religion of Islam is destructive and misleading, that is, deviating from the Qur'an and Hadith. Because the concept of man according to Islam is to know that man is the main goal under the creation of nature. This deviation is caused by a number of factors including:

1. Lack of understanding and concern, no true understanding of faith. As a result, they turn and leave and often violate or even oppose the true aqidah

2. Enthusiasm for traditional heritage and descendants (ancestors)

3. Obeying the words of a respected person blindly and failing to make the right choice based on the opinions of the Qur'an and Sunnah, so if his role model goes astray, then he will go astray.

4. It is excessive to love and lift up the saints and saints who have passed away, so that they can compare them with God or behave like God.

5. Neglect in studying the teachings of Islam due to the glare of western civilization. Often praises western thinkers and scientists and their technological achievements while accepting their behavior and culture

6. Education in the household is not based on Islamic teachings so that children grow up not knowing the Islamic creed. The role of official education that does not provide a sufficient portion to foster one's religion.

Among these beliefs that occur in the midst of society is a belief that links destiny and the good and bad of something with an event such as excessive sustenance with the birth of a baby by assuming that the baby is the bearer of sustenance or vice versa the birth of a baby brings bad luck and so on. In the book Peel Completely Bid'ah by Shaykh Ali Mahfuz they interpret from the words of the Prophet $\square$ from the narration of Al Bukhari from Ibn Umar which reads: Bad luck is in the house of women and horses, they misinterpret the meaning of the hadith. The above hadith is contextual, its meaning must be adapted to reality, in fact the content of the hadith wants to say that there is actually no bad luck or luck in something, there is imperfection in everything and humans have a choice in an effort to eliminate or minimize the imperfect nature. Good or bad in the provisions of Allah, not in the object. But Imam Ath-Thibi rejects that opinion and interprets the hadith not in its zohir, even Ath-Thibi also implys and denounces any object that causes bad luck and character.

\subsection{Criteria for Misunderstanding}

It was stated in the closing of the MUI National Working Meeting at the Sari Pan Pacific Hotel, Jl. MH. Thamrin, Jakarta, Tuesday (6/11/2007), the central MUI issued a fatwa for an ideology or religious sect to be declared heretical if it fulfills one of the following criteria: 1

1. Denying one of the 6 (six) pillars of faith

2. Believing and following the aqidah that is not in accordance with the syar'i arguments (Qur'an and Sunnah)

3. Believing in revelation after the Koran

4. Denying the authenticity or truth of the contents of the Koran

5. Doing the interpretation of the Koran that is not based on the rules of interpretation

6. Denying the position of the prophet's hadith as a source of Islamic teachings 
7. Insulting, harassing and demeaning the Prophets and Apostles

8. Denying Prophet Muhammad $\square$ as the last prophet and messenger

9. Changing, adding or subtracting the points of worship that have been determined by sharia, such as pilgrimage not to the Baitullah, obligatory prayers not 5 times a day

10. Disbelieving fellow Muslims without syar'i evidence is like disbelieving Muslims just because they are not in their group

According to the MUI and the statement from the Secretary of the Central MUI,

Drs. HM Ichwan Sam (at that time) that people can use these criteria to judge a sect is heretical or not, out of the teachings of Islam or not. If there is only one criterion that emerges from an understanding or sect, it can be sentenced as deviant and deviate from the true teachings of Islam.

As for several deviant sects that have arisen in North Sumatra, such as: Soul Training, Al-Haq, Deviant Recitation, and so on, have been overcome and declared deviant or heretical, so that Muslims stay away from these sects and eventually do not develop and die alone. As Allah says in the Qur'an, Surah Al-Isra verse 81 which means:

"And say: "The truth has come and the falsehood has disappeared". Indeed falsehood it is definitely something disappear".

All the people we have studied so far have some common characteristics, such as violating the boundaries that Allah has set, partnering with Him, acting arrogantly on earth, and arbitrarily controlling the property of others, tending to sexual deviant behavior and anger. Another common trait is their oppression and abuse of the Muslims around them. They will try various ways to intimidate the Muslims.

None of these things can save a person from Allah's punishment and punishment. As stated by Allah SWT in the Qur'an as follows:

"And did they not travel through the earth and see how the consequences (afflicted) on those who were before them? Those people are stronger than them (alone) and have cultivated the earth (land) and prospered it more than what they have prospered. And their messengers have come to them with clear proofs. So Allah never does wrong to them, but they do wrong to themselves." (Surat ar-Ruum, 30: 9)

From Abu Hurairah Ra, he said: "The Messenger of Allah said: 'The Jews have been divided into seventy-one (71) groups or seventy-two (72) groups, and the Christians have been divided into seventy-one (71) or seven twenty-two (72) groups, and my ummah will be divided into seventy-three (73) groups. Everyone goes to hell. Except for one group. "(They) The companions asked, "Who are they, O Messenger of Allah?" He sallallaahu 'alaihi wa sallam replied, "They are a group that is walking on the path taken by me and my companions." (Narrated by Abu Dawud, Tirmidhi, Ibn Majah).

Shihab al-Khafaji Rahimahullah ta'ala has said in the book Nasim ar-Riyadh: the group that survived they were the Sunnah wal Jama'ah.

In the book "Hasyiah Syanwani 'ala Mukhtashor ab Jamrah" it is explained that the Sunnah wal jama'ah are the al-Ash'ari group and the Imams of the Ulama, because Allah has made them as evidence against his creatures and those who hold on to them. They are what is meant in the Hadith: "My people will not gather (agree) in error". 


\subsection{The State of Islamic Education in the Millennial Era}

Despite the great expansion going so far, the state of education in the Islamic world is at its worst. Islamic education is mostly a private business that gets funding from the community. If state funds are available, then pressures for secularization will be imposed under the pretext of modernization and progress. This insistence usually divides into two distinct or rather contradictory sections between the Islamic and the modern sections.

Everything had been thought out and planned by colonial strategists. National independence has given the greatest impetus to the secular system, considering its own independence, pouring state funds into its system and increasingly secularizing it under the pretext of nationalism.

Although everything has been carried out with a system that is not in accordance with Islam, the result achieved is not a western-style education system, but only a caricature of it. The materials and methodologies that are now being taught in the Islamic world are copies of western materials and methodologies but do not contain the original insights and bring them to life in western countries. Without this insight, these materials and methodologies are only modest instruments. Without realizing it, this empty material continues to have a bad influence that de-Islamizes students by acting as an alternative to Islamic materials and methodologies and as an aid to progress and modernization.

The branches of science have now separated themselves from the Qur'an but actually these sciences are directly or indirectly the result of the study of the holy book. These sciences are very helpful for Islamic scholars in eliminating misunderstandings about Islamic teachings. According to Shahristani, there are four main problems that shake the minds of Muslims and ultimately lead to the birth of various schools of thought in Islam, namely:

1. The problem of freedom of will is whether humans have freedom of will or not and whether humans have the breadth of doing or not.

2. The problem with the attributes of Allah is whether Allah has attributes or not and if he has them whether those attributes are part of his substance or not.

3. The problem of democracy between belief and action is whether human actions are part of their faith or separate.

4. The dispute between reason and revelation is whether the true criterion of truth is reason or revelation. In other words, whether reason is the subject of revelation or revelation that is the subject of reason.

Regarding the problems mentioned above, which concern mankind the most are those related to matters relating to their religious practice. In every age humans have devoted their attention to issues such as whether the lord is a tyrant King who does as he pleases or he has given the authority to humans to determine the fate of humans themselves, but the problem has hitherto remained unsolved and remains complex. Therefore, it is not surprising that the thing that most concerns Muslims about philosophical thought and causes the severance of the bonds of Muslim unity is the issue of "freedom of will or the notion of absolute freedom".

Besides that, among humans there are those who have the belief in absolute freedom to act by believing that God has handed over to humans power and skills and humans are free or not to use them depending on their will.

Educational media and information media are currently reluctant to carry out their duties and roles as a means of social education and religious ethics. Even if there are, 
they are very few in number, even some media don't care about it at all. At the same time, print and electronic information media and cyberspace have become a means of destroying civilization and social values, humanity and morality, which only focuses on issues that are oriented towards interests and entertainment. From here, emerged the "naked" generation without weapons and powerless to fend off kufr and wickedness who were armed with very sophisticated and modern weapons.

\subsection{Solutions or Efforts to Fortify Aqidah Deviations}

MUI as a forum for Muslim scholars and intellectuals must take an active role in maintaining Islamic values and protecting people from any deviant understandings and sects, including by setting guidelines for dealing with a group or sect that is misguided or not based on analysis, study, and arguments. justifiable argument. This determination will be a bulwark or guideline for Muslims in assessing an understanding so that they can respond to it properly.

This deviation from the Islamic aqeedah cannot be allowed to just happen. It is fitting for these deviations to be immediately addressed and eliminated so that Muslims can return to teachings that are in accordance with Islamic law as stated in the Qur'an and Hadith.

Support from religious teachers and community leaders is also very important, both material and immaterial. This generation in the millennial era really needs a companion such as an ustadz so that they are not easily influenced by deviant sects.

\section{Conclusion}

Based on the explanation and discussion that has been stated above with all the shortcomings obtained by the researcher, it can be concluded that these deviations are strongly influenced by various factors such as knowledge, personality, environment, and also the economy. The solution to overcome this problem is to increase knowledge and also practice religious teachings, then get along well to find a good environment. Support from religious leaders, the community, and also parents is also very much needed. With the efforts of a religious approach through recitation, question and answer discussion activities, and other positive activities. By being religiously kaffah that is rahmatan lil 'alamin, at least this millennial generation will be ready to face various problems that are rolled out in the name of religion. 


\section{References}

Aat Suwanto. (2009). “Apa Siiih Ilmu”. Bandung : CV. Cipta Dea Pustaka

Arif Rahman, Diyah Mintasih. (2019). "Pendidikan Islam Di Era Revolusi Industri 4.0”. Depok : Komojoyo Press

https://www.muisumut.com/blog/2020/09/02/bahaya-aliran-sesat-penistaan-agama/

Ismail Raji al-Faruzi. (1982). "Ilmu Pengetahuan". Bandung : Perpustakaan Salman ITB

Kementrian Agama Republik Indonesia, Al-Quran Al-Karim Dan Terjemahnya, (Surabaya: Halim Publishing dan Distributing, 2014).

Pangulu Abdul Karim.(2017) "Fungsi Aqidah Dan Sebab-Sebab Penyimpangan Dalam Aqidah". Jurnal Pendidikan Islam dan Teknologi Pendidikan Vol.VII, No 1, Januari-Juni

Syahrin Harahap. (2016). "Jalan Islam Menuu Muslim Paripurna". Jakarta : Prenadamedia Group

Zaini, Roni Ramlan.(2019). "Penguatan Pendidikan Aqidah Anak dari Penyimpangan Budaya Online". Vol 14 No. 2, Tahun. 